\title{
The Use of Oral Admissions to Lift the Bar of the Statute of Frauds: UCC Section 2-201(3)(b)
}

The author argues that Uniform Commercial Code subsection 2-201 $(3)(b)$, which enables the defendant's admission of a contract for the sale of goods to lift the bar of the Statute of Frauds, should be read to allow the plaintiff to proceed at least to discovery, and under certain circumstances to trial, to ob'ain an admission. Read in this manner, the subsection will allow more oral contracts to be enforced, a result that accords with normal business practices. The author examines the historical background of the Statute of Frauds and the soundness of a rule allowing oral admissions to lift the bar of the Statute; discusses how the subsection should be applied procedurally; and compares the operation of the subsection to French methods of proving an obligation.

The Statute of Frauds was enacted in 1677 to protect innocent parties from fraudulent claims based on perjured testimony. The Statute was primarily concerned with ensuring that where a contract existed there would be reliable evidence of it; hence, the requirement of a writing. ${ }^{1}$ The English courts imterpretcd this requirement rigidly. Contracts were refused enforcement in the absence of a writing that conformed to the Statute's requirements, even though the plaintiff's claim appeared completely bona fide. A defendant could plcad the defense of the Statute while admitting that the contract existed. ${ }^{2}$ The Statute thus became a shield for persons seeking to evade oral agreements.

This rigid application of the Statute has been criticized on several grounds. ${ }^{3}$ It has been argued that courts, by insisting on detailed formal requirements, pronote the breach of contracts, and that the requirement of a signed writing ignores the coinmercial practice of relying on oral agreeinents. Because of these shortcomings, courts have often strained to find ways to take an agreement "out of the Statute."4

1. Stevens, Ethics and the Statute of Frauds, 37 CoRNELL L.Q. 355, 360 (1952) [hereinafter cited as Stevens]; see 2 A. CoRBIN, ConTracts § 498, at 680 (1950) thereinafter cited as CoRBin].

2. Stevens, supra note 1 , at 355-72.

3. See Corbin, The Uniform Commercial Code-Sales; Should It Be Enacted?, 59 YALE L.J. 821, 829 (1950); Stevens, supra note 1, at 359.

4. The courts have devised various ways to narrow the application of the Statute when it seems that to allow the defense of the Statute would produce fraud or inequitable 
This has caused the Statute to be applied inconsistently; the predictability that the Statute was designed to foster has not been achieved. Finally, it has been asserted that the reasons for the Statute have been largely eliminated. Although the threat that a perjuring plaintiff would succeed in enforcing a fraudulent claim may have been great in 1677, it is not nearly so serious today because our judicial system has developed since 1677 and become much more sophisticated.

Uniforn Commercial Code section 2-201 was drafted in response to such criticisms. The Code does not reject the concept of the Statute of Frauds; $;^{5}$ Professor Llewellyn and the other drafters felt that a provision to protect against fraud was still needed. ${ }^{8}$ Rather, section 2-201 seeks to preserve the useful functions of the Statute of Frauds while eliminating its abuses. It does this by emphasizing the need for proof while avoiding some of the requirements that attended the Statute. ${ }^{7}$

The Code retains certain basic requirements of the Statute of Frauds: that a writing evidence a contract for the sale of goods; that the writing be signed or authenticated in some manner which identifies the party to be charged; and that there be a specific quantity stipulated. The writing need not include price, time and place of payment or delivery, any particular warranties, nor need it state the general quality of the goods. ${ }^{8}$

results. See generally 2 CORBIN, supra note $1, \S 275$, at $3-9 ; 3$ S. WILIISTON, A TREATISE ON THE LAW OF CONTRACTS $\$ 448$, at $343-47$ (3d ed. 1960).

There are also statutory exceptions-part payment and delivery and acceptanceto the writing requirement when the case involves a sale of goods. 2 CorBin, supra note $1, \S 467$, at $607 ; 3$ S. WiLliston, supra $\$ 505$ at $629-31$.

5. The Statute of Frauds was repealed in England in 1954. Law Reform (Enforcement of Contracts) Act of 1954, 2 \& 3 Eliz. 2, c. 34, §§ 1-2. This action apparently was taken because the defense facilitated the breach of contracts and injured those with well-founded claims. See generally Decker, The Repeal of the Statute of Frauds in Britain, 11 AM. Bus. L.J. 55, 55-56 (1973) (discussion of which provisions repealed and which retained).

6. We feel quite definitely that there is some value in a Statute of Frauds. We think this point of view is held by most businessmen in most of the mercantile communities of the country. We recognize, of course, that a number of states have gotten along without any Statute of Frauds in the sale of goods. We are not flooded with complaints that fraud rides high, far, and all over in other states. On the other hand, on the whole in those communities in which there is a Statute of Frauds, there appears to be some value derived from it in some cases.

Statement of Professor Karl N. Llewellyn (May 20, 1950), reprinted in 2 ALJ, CoNsmERATION OF PROPOSED FinAL DRAFT OF THE UNIFORM COMMERCIAL CODE 296 (1950).

7. The comments to section 2-201 make this clear: "All that is required is that the writing afford a basis for believing that the offered oral evidence rests on a real transaction." UNIFORM COMMerctal CODE $\$ 2$ 2-201, Comment 1.

8. By not requiring that the writing include all the terms of the agreement, section 2-201 eliminates many inequities found in the old Statute of Frauds. Under the old rule, where a plaintiff came into court with a written memorandum, if the defendant could prove that there was an additional term not included in the writing, the writing 
Subsection 2-201(3)(b), however, departs significantly from the Statute of Frauds in allowing oral evidence to lift the bar of the Statute. This subsection provides that a contract may be enforced "if the party against whom enforcement is sought admits in his pleading, testimony, or otherwise in court that a contract for sale was inade." When such an admission is made, no writing is required. Subsection (3)(b), then, allows the plaintiff to seek an adinission from the defendant that a contract exists and precludes the defendant who admits an agreement from successfully pleading the Statute. ${ }^{10}$

This Comment will discuss the historical and practical reasons that support a rule allowing admissions to lift the bar of the Statute of Frauds, as well as those that militate against too broad a reading of subsection (3) (b). The Comment will next examine certain procedural issues that affect the operation of subsection (3)(b). It will argue that the subsection should be read to allow the plaintiff to proceed to discovery to obtain an admission froin the defendant. If the defendant unambiguously denies the contract in discovery, however, disinissal is required by the interests in protecting innocent defendants from unwarranted harassment and in promoting judicial economy. Such a reading of the subsection will lead to greater enforcement of oral contracts, ${ }^{11}$ a result that accords with commercial reality. Finally, this

was rendered insufficient as evidence of the agreement. Statement of Professor Karl N. Llewellyn (Feb. 15, 1954), reprinted in 1 N.Y. Law Revision CoMM'N ANN. Rep. 163 (1954). Under section 2-201, this is no longer possible. The plaintiff need only prove that an agreement of sale was made and the specific quantity involvcd. It was felt that adequate checks would be provided by market prices and other current valuations, the practice of the parties, and the custom of the industry. UNIFORM COMMRRCIAL CODE $\$ 2-201$, Cominent 1.

9. 3) A contract which does not satisfy the requirements of subsection (1) but which is valid in other respects is enforceable

b) if the party against whom enforcement is sorght admits in his pleading, testimony or otherwise in court that a contract for sale was made, but the contract is not enforceable under this provision beyond the quantity of goods admitted . . . .

UNIFORM COMMERCIAL CODE $\left.\$ 2-201(3)^{\prime} b\right)$.

10. Uniform Commercial Code $\$ 2-201$, Comment 7. Soe Yonge, The Unheralded Demise of the Statute of Frauds Welsher in Oral Contracts for the Sale of Goods and Investment Securities: Oral Contracts are Enforceable by Involuntary Admissions in Court under U.C.C. Sections 2-201(3)(b) and 8-319(d), 33 WASH. \& LeE L. Rev. 1 (1976) [hereinafter cited as Yonge].

11. Since Article 2 of the Uniform Commercial Code covers only sales of goods, the change in the Statute of Frauds introduced by section 2-201 is linited in scope. See UNIFORM COMMERCIAL CODE $\$ \S 2-201,2-102$. Should subsection (3)(b) prove to be useful and reliable, however, a change in judicial and legislative attitudes towards proof of contract in other areas may be forthcoming. See Perillo, The Statute of Frauds in the Light of Functions and Dysfunctions of Form, 43 FoRDHAM L. REv. 39, 70 (1974) [hereinafter cited as Perillo]. Subsection 8-319(d) of the Code, dealing with the sale of securities, is similar to subsection 2-201(3)(b). It provides: "A contract for the 
Comment will analyze French methods of proving a contract, as they provide useful models for the practical application of subsection (3) (b).

\section{I}

\section{The Rationale of Subsection (3)(b)}

Subsection (3)(b) rests on at least two basic assumptions: (1) that a defendant's oral admission is reliable evidence of the existence of a contract; and (2) that a defendant will admit an existing contract when called upon to do so. To evaluate subsection (3) (b), the validity of these assumptions must be examined.

In support of the assumption that a defendant's adinission is reliable, it has been asserted that such an admission should be "accorded the high degree of probity usually given to statements against interest."12 Because the defendant's admission that a contract exists is agamst his interest, there is a danger that he will misrepresent the terms of the agreement. Subsection (3)(b) protects against this potential abuse in three ways. First, it contemplates that the price term may be supplied by current market prices. ${ }^{13}$ Second, it does not suppose that the defendant's admission conclusively establislies the contract. The plaintiff is not held to the terms admitted by the defendant; rather, these terms remain subject to further proof. $^{14}$ Third, it restricts the admissions that will substitute for a writing to those made under oath as part of a judicial proceeding. This restriction sliould operate to discourage misrepresentations by the defendant.

Related to the question of whether the defendant will misrepresent the terms of the agreement is whether the defendant will admit in the first place that an agreement exists. The Califorma legislature rejected subsection (3)(b) on the rationale that it would encourage the defendant to perjure himself. ${ }^{15}$ A defendant may well be tempted

sale of securities is not enforceable by way of action or defense unless . . . the party against whom enforcement is sought admits in his pleading, testimony or otherwise in court that a contract was made for sale of a stated quantity of described securities at a defined or stated price."

12. Yonge, supra note 10 , at 19.

13. Uniform Commercial Code \$ 2-201, Comment 1.

14. Id., Comment 7.

15. Report of Professors Harold Marsh, Jr. and William D. Warren, reprinted in Senate Fact Finding Committee on Judiciary, The Uniform Commercial Code 436,449 (1961). The California Legislature also found subsection (3)(b) to be unacceptably vague and indefinite. In particular, it was felt that subsection (3)(b) was unclear concerning the effect that would be given a demurrer, that a demurrer might be construed as an admission under subsection (3)(b), lifting the bar of the Statute of Frauds. This was found objectionable because California procedure allows the Statute of Frauds to be raised by demurrer under certain circumstances. Id. See Cal. Code 
to commit perjury; by falsely denying a contract, he unay escape an obligation that he has already indicated an interest in avoiding. This temptation is undoubtedly enhanced by the small likelihood that the defendant will ever have to account for his behavior; the threat of a perjury prosecution is insignificant. ${ }^{18}$ The drafters of subsection (3) (b) were not impressed by this line of argument, however, reasoning: "[E]xactly the same thing is true in regard to every litigation of every point of fact in any litigation in a state which requires sworn pleadings." ${ }^{17}$ The Permanent Editorial Board of the Uniform Commercial Code commented tersely that the objections of the California legislature to subsection (3)(b), based on the argument that the subsection encouraged perjury, lent nothing new to the discussion of the subsection. ${ }^{18}$

The subsection was drafted to give the plaintiff an opportunity to at least ask the defendant to admit or deny making the agreement and to preclude the defendant from admitting the existence of the agreement while using the Statute of Frauds as a defense. ${ }^{10}$ The defendant is forced, in the absence of other defenses, to commit perjury to avoid the obligation. Whether or not this will lead to the enforcement of more oral contracts, it deprives the defendant of a morally comfortable escape route whereby he can admit the agreement yet avoid its consequences through a defense that the law has approved.

It should not be too readily assumed that defendants will commit perjury to avoid their oral agreements. One strong deterrent is the potential harm to the defendant's business reputation that the false denial of a contract may cause. Other businessmen might hesitate to enter into oral agreements with the defendant, to rely on his word, or perhaps even to deal with him if it were felt that he had lied in a judicial proceeding to escape his obligation. Further, there nnay be merit to the assertion that the "[h]uman conscience makes distinctions that plead-

Crv. Pro. $\$ 430.10$ (West Supp. 1976) (demurrer allowed if it cannot be ascertained from the complaint whether the contract is written or oral); Harper v. Goldschmidt, 156 Cal. 245, 104 P. 451 (1909) (when a complaint shows on its face that the alleged contract is withm the Statute of Frauds and that the Statute has not been satisfied, a demurrer will be sustained). For an analysis of this argument, see text accompanying notes 30-34 infra.

16. See McClintock, What Happens to Perjurers, 24 MinN. L. Rev. 727 (1940); Comment, Attorneys and Subornation of Perjury, 26 MAINe L. Rev. 297, 299 (1974); Comment, Perjury: The Forgotten Offense, 65 J. Crim. LAw \& CRIMINologY 361 (1974).

17. Comments of Karl N. Llewellyn (May 20, 1950), supra note 6, at 297.

18. PERMANENT EDITORIAL BOARD FOR THE UNIFORM COMMERCIAL CODE, REPORT No. 2, at 32 (1965).

19. UNIFORM COMMERCIAL CODE $§ 2-201$, Comment 7. 
ing rules do not. We need not accept as universal the proposition that men will lie under oath whenever it is in their interest to do so."20

Critics of subsection (3)(b) have argued that in circuinventing the writing requirement subsection (3)(b) erodes the evidentiary, cautionary, and channeling functions served by the Statute of Frauds. The evidentiary function is the most obvious-if a contract must be in writing, then the writing serves as "evidence of the existence and purport of the contract, in case of controversy." 21 Requiring that a contract be in writing also serves a cautionary function as such a requirement may prevent hasty or ill-considered action. ${ }^{22} \mathrm{~A}$ channeling function is served in that the requirement of a writing helps the court decide whether a contract has been formed; this function has been described as "the facilitation of judicial diagnosis." 23 The Statute of Frauds, however, no longer serves the channeling and cautionary functions well because of the inconsistent and arbitrary manner in which the Statute and its exceptions have been applied. ${ }^{24}$ The Statute continues to serve an evidentiary function, but subsection (3)(b) also serves this function; it cannot be seriously doubted that an admission provides evidence of a "high degree of probity."25

It may also be asserted that subsection (3)(b) is unnecessary because plaintiffs are protected by reliance or restitution theories. Subsection (3)(b), however, provides relief to plaintiffs not protected by reliance or restitution theories; even where these theories are available, it often provides greater protection since the subsection may make expectation dainages recoverable by the plaintiff. ${ }^{26}$ Frequently no benefit is conferred in Statute of Frauds cases, preventing the plaintiff from recovering on a restitution theory. In addition, the reliance interest is often very difficult to measure. ${ }^{27}$ Nonaction as reliance, though it

20. Degnan, The Evidence Law of Discovery: Exclusion of Evidence Because of Fear of Perjury, 43 Texas L. Rev. 435, 449 (1965). The perjury problem can pose an ethical dilemma for the defendant's attorney. How does he advise his client when he knows that the client faces little risk of a perjury prosecution? Cleariy, he cannot advise his client to perjure himself. See, e.g., CaL. BUs. \& PROF. CoDE $\$ 6076$, Rule 7-101 (West Supp. 1976) (advising the violation of law). Is it incumbent upon him, however, to inform his client of the small risks involved? Should he tell his client of the subsection (3) (b) rule and let the client draw his own inferences? Even though the attorney knows that his client has made the alleged oral contract? These questions seem to pose problems that are present in any litigation, however.

21. See Fuller, Consideration and Form, 41 CoLUM. L. REv. 799, 800 (1941).

22. Id.

23. Id. at 801 .

24. See Perillo, supra note 11 , at $56,70-71$.

25. Yonge, supra note 10, at 19 . See text accompanying note 12 supra.

26. See UNIForm COMMERCiAL CODE $\$ \$ 2-701$ to 725.

27. In some Statute of Frauds' cases, restitution damages are also difficult to measure as they are linked to the plaintiff's reliance. See Dawson, Restitution or Damages?, 20 Orno ST. L.J. 175, 191 (1959). 
may cause injury, is not easily measured. Subsection (3)(b) thus offers a more effective ineans of recovery for relying plaintiffs.

Hale v. Higginbotham ${ }^{28}$ illustrates well the gap filled by subsection (3)(b) in providing relief to plaintiffs injured by reneging defendants. The plaintiff had agreed to buy the remainder of the defendant's "milk base" in an oral agreement made after an auction, but the defendant subsequently refused to comply. The Georgia Supreme Court held that the defendant's admission in court that a contract had been made was sufficient under subsection (3)(b) to lift the bar of the Statute, and specific enforcement of the contract was granted. The plaintiff could not have recovered on either a restitution or a reliance theory since there had been no benefit conferred and no reliance other than nonaction; without subsection (3)(b), the plaintiff would not have had specific performance for the defendant's breach.

Neither is the plaintiff as adequately protected by the equitable estoppel doctrine. Application of the doctrine is often unclear and arbitrary; further, its use is limited since it requires some measurable degree of compliance with the agreement by the plaintiff. ${ }^{20}$

At a ininimum, then, subsection (3)(b) prevents a defendant froin admitting a contract while raising the Statute of Frauds as a defense to its enforceinent. It is clear, however, that the subsection may be used more broadly to enforce otherwise unenforceable obligations; its scope will depend upon how far courts are willing to allow the plaintiff to proceed and the scope they are willing to give to the concept of an admission.

\section{II}

\section{The SCOpe of Subsection (3)(b)}

Any tendency to give subsection (3)(b) a broad reach is tempered by the policies, embodied in the Statute of Frauds, that imnocent defendants should be shielded from baseless lawsuits and that judicial resources should not be wasted.

This section will examine several procedural issues raised by subsection (3)(b); whether raising the defense of the Statute of Frauds by demurrer will prevent a plaintiff froin proceeding to discovery where lie might be able to elicit an admission from the defendant that will satisfy subsection (3)(b); whether an admission made in a defendant's pleading, testimony at discovery, or testimony on cross-examination at trial will be dispositive of the Statute of Frauds issue; and the effect

28. $228 \mathrm{Ga} .823,188$ S.E.2d 515 (1972).

29. See 3 S. Williston, supra note 4, § 533A, at 809; Comment, Equitable Estoppel and the Statute of Frauds in California, 53 CALIF. L. ReV. 590, 608-09 (1965). 
of a defendant's unambiguous denial of the contract despite contrary evidence. These issues all relate to one essential inquiry: At what point should a plaintiff seeking an admission from the defendant be precluded from proceeding further? The effectiveness of subsection (3)(b) in enforcing oral agreements will largely be determined by where this line is drawn.

One court has expressly held that the practice of raising the Statute of Frauds by demurrer ${ }^{30}$ should not prevent the plaintiff from proceeding to discovery. In Garrison v. Piatt, ${ }^{31}$ the court refused to sustain a demurrer based on the Statute of Frauds, reasoning that the plaintiff should not be denied the opportunity to elicit an admission from the defendant during discovery. ${ }^{32}$ The court thought that the legislature, by adopting subsection (3)(b), intended to test the enforceability of the contract through the answer or testimony of the party resisting enforcement. This result has been criticized for allowing too much harassment of innocent defendants by perjuring plaimtiffs. ${ }^{33}$ If demurrers based on the Statute of Frauds were sustained, however, subsection (3)(b) would be rendered effectively inoperative; barred from proceeding to discovery, the plaintiff would not have an opportunity to elicit an admission from the defendant.

It makes little sense to enact subsection (3)(b) but deprive it of any practical effect. Further, a demurrer based on the Statute of Frauds is inappropriate; given subsection (3)(b), the plaintiff's complaint will state a sufficient legal claim by simply alleging an oral contract. Subsection (3)(b) makes it quite clear that under certain circumstances oral contracts may be enforced. Thus, the lack of a writing does not by itself destroy the legal sufficiency of the plaintiff's claim. It would seem, then, that the approach in Garrison is sound. The importance of a demurrer in this situation is, in any event, decliming, as the proper procedure today in most jurisdictions is to raise the Statute of Frauds as an affirmative defense. ${ }^{34}$

30. Plaintiffs have traditionally been allowed to raise the Statute of Frauds by demurrer. Stevens, supra note 1, at 374. Even before the drafting of subsection (3)(b), it had been suggested that "the ethical interpretation and application of the statute . . . should rule out the propriety of the demurrer. The plaintiff . . . should be entitled to a sworn admission or denial of the making of the agreement." Id. at 375 .

31. 113 Ga. App. 94, 147 S.E.2d 374 (1966).

32. Id. at 95,147 S.E.2d at 376.

33. Note, Placing Fraud Back Into the Statute of Frauds-U.C.C. 2-201, 6 AM. Bus. L.J. 602 (1968).

34. See Yonge, supra note 10, at 2 n.10. E.g., FED. R. Crv. P. 8(c).

At least one court has raised the question of whether a demurrer is a sufficient admission under subsection (3)(b). In Beter v. Helman, 41 Westmoreland I.J. 7 (C.P. Westmoreland County, Pa. 1958), the court held that a demurrer did not constitute a sufficient admission, reasoning that the subsection applied only to an admission made in a responsive pleading. This is the proper result since a demurrer involves no factual 
Subsection (3)(b) expressly provides that an admission made in the pleadings of a contract's existence will render the contract enforceable despite the absence of a writing. ${ }^{35}$ The effect of a defendant's denial of an agreement, however, is less clear. In Reissman International Corp. v. J.S.O. Wood Products, Inc., ${ }^{36}$ the court denied the defendant's motion for dismissal because of the possibility that the plaintiff would obtain a testimonial admission from the defendant in discovery. ${ }^{37}$

If subsection (3)(b) was intended merely to change the rule that a defendant could admit the contract yet plead the Statute as a defense, a result honoring the defendant's denial in the pleadings would be adequate. By allowing the plaintiff to proceed to discovery despite the defendant's denial in his answer, the court increases the likelihood that an innocent defendant will be harassed by a plaintiff willing to commit perjury. Where there is evidence tending to contradict the defendant's denial, ${ }^{38}$ the language and policy of subsection $(3)(b)$ dictate that the plaintiff be permitted to proceed to discovery to question the defendant on the evidence of the alleged contract. Where the plaintiff produces no such evidence to contradict the defendant's denial, it may be argued that the denial should be honored in the interests of judicial economy and protection of innocent defendants. Even in the absence of contrary evidence, however, the plaintiff should be allowed to question the

admission. 2 CoRBIN, supra note $1, \S 519$, at 759 . A demurrer admits the truth of the facts in the complaint for the limited purpose of questioning the sufficiency of those facts as a legal basis for relief. F. JAMES, CIVIL Procedure \& 4.1, at 127 (1965).

35. Prior to the enactment of the Uniform Commercial Code, the cases were split on whether an admission made in the defendant's pleading would satisfy the Statute's requirement of a written memorandum. Some courts that did not give effect to such an admission reasoned that the pleading was made under a "legal compulsion." Professor Corbin theorized that these cases might have derived from the notion that a party should not be compelled to testify against himself. 2 CoRsin, supra note 1 , $\$ 519$ at 757-58. Other pre-Code cases, however, simply held that the dcfendant could not admit the agreement and plead the Statute as a defense. See id. at 757 n.45; Garnsey v. Gothard, 90 Cal. 603, 27 P. 516 (1891) (defense of Statute of Frauds not plcaded but court considered question of whether the trust agreement had to be in writing); Zlotziver v. Zlotziver, 355 Pa. 299, 49 A.2d 779 (1946) (purposes of Statute of Frauds may be attained by admissions either in pleadings or in testimony).

The result under the Code is clear. See, e.g., Rochester Iron \& Metal Co. v. Capellupo, 62 Misc. 2d 264, 307 N.Y.S.2d 133 (Monroe County Ct. 1969). The defendant had endorsed a check to the plaintiff for goods sold and delivered, but the check was subsequently dishonored. The defendant did not deny delivery of the goods, but he claimed that the goods were defective and that the Statute of Frauds barred the action. The court held that the answer showed that the defendant had received and retained the goods and thus could not rely on the Statute of Frauds because of subsections 2-201(3) (b) and (c).

36. 10 UCC Rep. SERv. 1165 (Civ. Ct. N.Y. County 1972).

37. "The possibility exists that plaintiff there or on trial may be able to obtain an admission by defendant of the entire contract as claimed." Id. at 1168.

38. In Reissman, an invoice referred to the purchase order of the alleged contract. Id. at 1167. 
defendant in discovery so that subsection (3)(b) may be utilized as a tool for probing the circumstances of an alleged agreement, rather than becoming a formal exercise in pleading practice in which the plaintiff will allege the oral contract and the defendant will deny it pro forma without being subjected to the plaintiff's scrutiny. Such a reading would accord with the broad language of the subsection as well as its underlying policy of encouraging the enforcement of oral agreements.

The language of subsection (3)(b) suggests that the defendant's admission of the contract in discovery will suffice to lift the bar of the Statute of Frauds. Two courts that considered this issue, however, treated admissions made in discovery in apparently different ways. ${ }^{39}$

In Cohn v. Fisher, ${ }^{40}$ the defendant admitted the contract both in his deposition and at trial. In addition, the plaintiff had a check from the defendant that bore a notation suggesting that the defendant had made an agreement to purchase a boat from the plaintiff. The court held that either the admission or the check would have been sufficient by itself to lift the bar of the Statute of Frauds. The Court articulated its comprehension of subsection (3)(b):

[I]f a party admits an oral contract, he should be held bound to his bargain. The statute of frauds was not designed to protect a party who made an oral contract, but rather to aid a party who did not make a contract, though one is claimed to have been made orally with him. ${ }^{41}$

A different result was reached in Presti $v$. Wilson. ${ }^{42}$ The defendant admitted the contract in his deposition, but later denied it in his testimony at trial. The court found the earlier admission immaterial,

39. A majority of pre-Code cases held that an admission made in a deposition could not serve as a written memorandum sufficient to satisfy the Statute of Frauds because the answers in the deposition were not "voluntarily given." See, e.g., Keans, Springmen \& Stipek Inc. v. Alphonzo E. Bell Corp., 126 Cal. App. 2d 311, 272 P.2d 35 (2d Dist. 1954). Many of these decisions illustrate the confusion as to the purpose and application of the Statute of Frauds that abounded prior to the drafting of the Uniform Commercial Code. One court based its decision on the premise that the Statute of Frauds was intended to prevent verbal agreements. Haskell v. Heathcote, $363 \mathrm{~Pa}$. 184, 69 A.2d 71 (1949) (the court refused to allow the plaintiff to depose the defendant to elicit an admission of the agreement). Another court stated that the Statute would be rendered a nullity if an admission made in a deposition from prior litigation were accepted as evidence of the alleged agreement. Smith v. Muss, 203 Misc. 356, 117 N.Y.S.2d 501 (Sup. Ct. 1952), appeal dismissed, 281 App. Div. 957, 122 N.Y.S.2d 377 (1953). Some pre-Code cases did accept depositions as a sufficient memorandum under the Statute of Frauds. See, e.g., Kellogg v. Peddicord, 181 Ill. 22, 54.N.E. 623 (1899).

40. 118 N.J. Super. 286, 287 A.2d 222 (1972).

41. Id. at $296,287 \mathrm{~A} .2 \mathrm{~d}$ at 227.

42. 348 F. Supp. 543 (E.D.N.Y. 1972). 
reasoning that subsection (3)(b) was not satisfied since at trial the defendant repudiated the admission he had made during pretrial proceedings. The court might have found that the existence of an agreement was not adequately proved without discounting completely the defendant's admission in his deposition. The evidence produced at trial might have effectively undermined the credibility of that admission; there may not have been sufficient evidence, independent of the pretrial admission, to convince the trier of fact that a contract had been made. The court refused to consider the pretrial admission, ${ }^{43}$ however, citing a pre-Code case ${ }^{44}$ in which an involuntary admission was held not to satisfy the Statute of Frauds. Since admissions may be compelled under subsection (3)(b), the court's reliance seems misplaced. Where a defendant admits the agreenent during discovery, but later denies it, the trier of fact should decide on the basis of all the evidence-including the pretrial admission-whether an agreement was made. The prior admission should be determinative of the Statute of Frauds question, leaving for further investigation at trial only the issue of whether the contract actually had been executed. The defendant's prior admission would be weighed in this deternnination, but his subsequent denial and other evidence that might diminish the force of the admission would also be considered.

Where the defendant does not deny that an agreement exists, the plaintiff should be permitted to proceed to trial. But even where the defendant does deny the contract in pretrial proceedings, if the denial is ambiguous the plaintiff should be allowed to proceed as long as he can adduce evidence of the contract's existence that casts doubt on the defendant's testimony. ${ }^{45}$ Such evidence ought to cause the plaintiff's interest in asserting his claim in court to prevail since it tends to show that the defendant is not innocent and therefore is not being subjected to unwarranted harassinent.

Courts have been unanimous in holding that an admission made during cross-examination at trial is sufficient to lift the bar of the Statute. ${ }^{46}$ Far more troublesome is the question of the effect to be given a denial by the defendant in the face of contradicting evidence.

43. Id. at 545 .

44. Smith v. Muss, 203 Misc. 356, 117 N.Y.S.2d 501 (Sup. Ct. 1952), appeal dismissed, 281 App. Div. 957, 122 N.Y.S.2d 377 (1953).

45. Cf. Reissman Int'l Corp. v. J.S.O. Wood Corp., 10 UCC REP. Serv. 1165 (Civ. Ct. N.Y. County 1972); see text accompanying notes 36-38 supra.

46. See, e.g., Hale v. Higginbotham, 228 Ga. 823, 188 S.E.2d 515 (1972); Quad County Grain Co. v. Poe, 202 N.W.2d 118 (Iowa 1972); Providence Granite Co. v. Joseph Rugo, Inc., 362 Mass. 888, 291 N.E.2d 159 (1972); In re Particle Reduction Corp., 60 Berks. L.J. 65 (E.D. Pa. 1968). This fulfills the language of subsection (3)(b) which expressly refers to admissions made in "pleading, testimony or otherwise in court." 
One court has held that the defendant's denial should be dispositive of the case. In $\operatorname{Cox} v . \operatorname{Cox}_{{ }^{47}}$ the plaintiff-buyer alleged an oral agreement with the defendants to buy their 1973 crop of cotton. He then entered into written contracts with cotton mills to deliver at specified prices. When the price of cotton rose, the plaintiff sought to enjoin the defendants froin breaching the oral contract. Although one of the defendants denied the contract, the trial court found that contrary evidence was sufficient to justify issuing the injunction. ${ }^{48}$

The Alabama Supreme Court reversed, holding that the trial court's "adverse credibility finding" could not substitute for an admission. The court followed traditional reasoning:

[T] ]he controversy in the evidence over the agreement indicates the very purpose of the Statute of Frauds-to prevent such controversies. If the agreements had been in writing, this controversy may never have developed. ${ }^{49}$

The court so held even though the defendant admitted the making of the agreement at the appellate level. This is a troublesome result; the Alabama Supreme Court gave effect to the defendant's denial, knowing that it was perjured. It ignored the other evidence, including the party's later admission at the appellate level. It may seem inequitable that the denial of a contract cannot be overruled by contradictory evidence where it is suspected that the denial is perjured. Yet, the Alabama Supreme Court was probably correct in holding that the "adverse credibility finding" of the trial court could not substitute for an admission by the defendant, especially in the face of the defendant's explicit denial. Section 2-201 of the Uniform Commercial Code bars the enforceInent of a contract in the absence of specified evidence; since the trial court did not find that any of the threshhold requirements of section 2-201 were met, enforcement of the contract was properly held to be barred. Any other result would do away with the Statute of Frauds completely. The Uniform Commercial Code retained the Statute of Frauds and subsection (3)(b) lifts that bar only in the event of the defendant's admission; thus, the trial court's determination in Cox is not justified, even though the defendant's denial may have been perjured.

One court has upheld the sufficiency of an adverse credibility finding as an adnission under subsection (3)(b). In Dangerfield v. Mark-

47. 292 Ala. 106, 289 So. 2d 609 (1974).

48. The trial court made this finding primarily because the plaintiff had entered into written collateral agreements to sell the cotton to large cotton mills. The court expressed its fear that the entire cotton industry would suffer if it did not issue an injunction to compel the defendants to comply with their agreement. Id. at 110, 289 So. $2 \mathrm{~d}$ at 611.

49. Id. at 111,289 So. $2 \mathrm{~d}$ at 612. 
$e l,{ }^{50}$ a farmer-seller counterclaimed, alleging the buyer's breach of his agreement to purchase the farmer's 1971 potato crop. The farmer alleged an agreement for the delivery of 27,000 hundredweight, and a subsequent agreement for an additional 14,000 hundredweight of potatoes; the seller further alleged that the buyer had accepted only 25,957 hundredweight. The buyer denied the subsequent agreement for the additional 14,000 hundredweight, and argued that even if such an agreement had been made, it would be unenforceable because of the Statute of Frauds. The trial court struck the counterclaim, but the North Dakota Supreme Court reversed, relying on subsection (3)(b). It found guidance in a lime of Iowa decisions interpreting a Statute of Frauds provision similar to subsection (3)(b): ${ }^{51}$

The Iowa court has also noted that the defendant need not admit there is a contract or admit the contract in the exact terms clained by the plaintiff [in order for the agreenent to satisfy the Statute of Frauds]. While the defendant's testimony on this point may not be added to or contradicted by other evidence, the testimony is subject to the ordinary rules of proof. If a fair consideration of his testiinony, and its implications under the circumstances established by the record, establishes the clained agreement, it will be enforced. ${ }^{62}$

Dangerfield extends subsection (3)(b) significantly. To construe the subsection as permitting a "fair consideration" of the defendant's testimony, ${ }^{53}$ so that a court, through an adverse credibility finding, may deem that testimony to constitute an admission, involves an extremely expansive reading of subsection (3)(b) that could limit substantially the need for a writing under the Statute of Frauds. This result does not follow from the language of the statute which lifts the bar of the Statute of Frauds in the face of the defendant's admission; it is a distortion of the concept to construe an admission to include an adverse credibility fmding. Where the defendant fails to make an unambiguous denial, however, a rule allowing a "fair consideration" of the defendant's testimony is sound considering subsection (3)(b)'s policy of encouraging the enforcement of oral contracts. But this rule should not override the defendant's explicit and unambiguous denial. Transforming such a denial into an admission through an adverse credibility finding disregards the language of subsection (3)(b).

Thus, the defendant's unambiguous denial at any stage of the proceedings after the pleadings, unless it contradicts a previous admission, should dispose of the Statute of Frauds issue.

\footnotetext{
50. 222 N.W.2d 373 (N.D. 1974).

51. For the text of the Iowa statutes, see note 111 infra.

52. 222 N.W.2d at 378.

53. See Olsen v. Peregoy \& Moore Co., 182 Iowa 889, 890, 165 N.W. 202 (1917).
} 
III

\section{A Comparison of the French System of Proof and Subsection (3)(b)}

The French procedures and requirements for proving a contract are quite flexible. Because it does not rely entirely on written memoranda, the French system may be usefully examined as a model of the ways that subection (3)(b) might be utilized.

Commercial transactions in France are not subject to any writing requirement; ${ }^{54}$ the admissibility of oral evidence is left to the discretion of the judge. This goes beyond subsection (3)(b), which represents the widest departure from a writing requirement that the drafters of the Uniform Commercial Code were willing to make. ${ }^{55}$ Where commercial contracts are not involved, the French requirements for proving a contract are similar to those of the Uniforın Commercial Code, and the procedures used to satisfy those requirements are comparable to the procedures available in American courts.

The basic rule is found in article 1341 of the Code civil. ${ }^{56}$ This statute is a direct descendant of the Ordonnance de Moulins, which was first passed in 1566 because the testiunony of witnesses was becoming

54. See C. Civ. art. 1341 (63e ed. Petits Codes Dalloz 1964); C. CoM. art. 109 (64e ed. Petits Codes Dalloz 1968). Such transactions are exempted from the requirement of a writing because they occur quickly and because merchants are required to keep books. 5 Encyclopédie JuRimique, Répertoire de Droit Civil, Preuve $\uparrow 325$ (1974) [hereinafter cited as Droit CIVIL].

The general policy of these exemptions is to be sought for in the desire to re-

frain from unnecessarily shackling commercial undertakings, the multiplicity

of which call for dispatch and simplicity and freedom from formal restrictions.

O. Bodington, AN OUTLine of THE FRench LAw of Evidence 81 (1904) [hereinafter cited as BoDINGTON].

There has been a somewhat limited movement back to requiring some kind of writing in certain commercial transactions. These exceptions to the general rule have been enumerated by the French legislature. See 2 EnCYClopédie JuRIdique, Procédure CIVILE et Commerciale, Preuve $\{1411$ (1956) [hereinafter cited as Procédure Civile]; 2 H. Mazeaud, L. Mazeaud, \& J. Mazeaud, Leçons de Droit Crvil 424 (4e ed. 1965) [hereinafter cited as MAZEAUD].

55. Article Two of the Uniform Commercial Code is comparable to the commercial transactions exception of the French system in that it applies only to sales of goods. See UNIFORM COMMERCIAL CODE \$§ 2-101, 2-102.

56. An instrument must be executed before a notary or under private signature for all things exceeding the amount of value of [50] francs even for voluntary deposits, and no proof by witnesses against or beyond the contents of an instrument, nor as to what is alleged to have been said previously, at the time of or since it was made, shall be allowed even though an amount of less than [50] francs is involved.

All of which is without prejudice to what is prescribed in the statutes relating to commerce.

Translation from: A. Von MeHren, The Civil LAw System 869 (1957) [hereinafter cited as Von MEHREN]. The translation refers to a sum of 5000 francs; this amount has been changed to 50 francs. See C. Crv. art. 1341 (63e ed. Petits Codes Dalloz 1964). 
increasmgly distrusted. ${ }^{57}$ Prior to the enactment of the Ordonnance de Moulins, the French rule had been "temoignages passent lettres" (testimony surpasses writing); with the Ordonnance, the rule became "lettres passent temoignages." 88

Article 1341 of the Code civil continued the practice of preferring written proof to testimony. ${ }^{59}$ Justifications offered by French scholars are similar to those asserted for the Statute of Frauds: to make the parties more aware of the transaction, to prevent misunderstanding, and to record the agreement accurately. ${ }^{\circ 0}$ The rule originated by the Ordonnance de Moulins was so strict that exceptions were quickly developed. By 1667 , numerous exceptions had already evolved. ${ }^{01}$ The requirement of a writing is avoided today where: (1) the transaction involves less than 50 francs; $^{\circ 2}$ (2) it is impossible to procure a writing; ${ }^{63}$ (3) the transaction is a commercial transaction; ${ }^{64}$ or (4) there is a "commencement de preuve par écrit," or beginning of written proof. ${ }^{05}$ In addition, either an answer given in a decisive oath or an admission may also substitute for the writing required by article $1341 .^{\circ 6}$ The next two sections will focus on the use of the admission, the decisive oath, and the exception for a beginning of written proof. These concepts are used in a broad and flexible way to provide alternatives to a strict writing requirement as means for proving a contract.

\section{A. The Decisive Oath and the Admission: Full Substitutes for a Writing}

An admission or an answer given in the procedure of the "serment

57. See J. Brissaud, A History of French Private Law 511 (2d ed. R. Howell transi. 1912).

58. Id. at 511-12.

59. See Bodington, supra note 54 , at 42 .

60. See 2 M. Planiol \& G. Ripert, Traite elémentaire de Droit Civil de Planiol $\| 2200$ (4e ed. G. Ripert \& J. Boulanger 1952) [hereinafter cited as Planiol \& RIPERT].

61. See Rabel, The Statute of Frauds and Comparative Legal History, 63 L.Q. REv. 174, 177 (1947).

62. C. Civ. art. 1341 (63d ed. Petits Codes Dalloz 1964). See MazeAud, supra note 54 , at $414,420-25$.

63. C. Crv. art. 1348 (63e ed. Petits Codes Dalloz 1964). This provision was designed to cover two situations: (1) Where it was impossible to procure a writing at the time the obligation was formed as in the case of a tort, see BoDINGTON, supra note 54 , at 52 ; or (2) when a subsequent event, such as a fire, has destroyed the writing. See generally MAZEAUD, supra note 54, at 422.

64. See C. Civ. art. 1341 (63e ed. Petits Codes Dalloz 1964); C. Com. art. 109 (64e ed. Petits Codes Dalloz 1968). Although article 109 of the Code de commerce speaks only of purchases and sales, the article is broadly construed. See Drolt CiviL, supra note 54, Preuve $\mathbb{1} 324$.

65. C. Crv. art. 1347 (63e ed. Petits Codes Dalloz 1964).

66. The decisive oath and admission are technically not exceptions to the rule of article 1341; rather, they are recognized as alternative methods of proving the contract. Drorr Crvin, supra note 54, at Preuve If 170; cf. MAZEAUd, supra note 54, at 414, 430. 
décisoire," ${ }^{\circ 7}$ or decisive oath, may be substituted for a writing that fulfills the formal requirements of article 1341; a judge must give each full value as evidence of a contract. ${ }^{68}$

The decisive oath is the procedure most foreign to our system of proof. $^{69}$ It differs from other modes of proof in that it is used not merely to establish a fact, but to end the litigation. ${ }^{70}$ The procedure is simple; either party may ask the judge to administer an oath to the opposing party ${ }^{71}$ concerning an issue that is critical to the case. ${ }^{72}$ The party to whom the oath is administered may either admit or deny the question posed, or demand that the oath be administered to the party who originally resorted to the procedure. When a party swears an answer under the oath, the issue is finally and conclusively decided. Once adopted, this procedure substitutes for all other forms of proof. ${ }^{73}$ It can be used in all cases, even when there is no writing. ${ }^{74}$ The issue thus determined cannot be reversed in an action for perjury. ${ }^{75}$ The procedure reflects the policy that a party who voluntarily adopts this method of proof, knowing that the other party may commit perjury, must bear the consequences of his choice. ${ }^{78}$ It is thought that the participation of both parties in this procedure lessens the likelihood of perjury. ${ }^{77}$

In a suit to enforce an oral contract, the defendant may lose if he cannot stand by his demial of the contract with his oath; his unwillmgness to take the oath may decide the case against him. ${ }^{78}$ The judge has wide discretion in deciding whether to administer this oath. ${ }^{79} \mathrm{He}$ may refuse to admimister it if he thinks that the case is already proved in favor of one of the parties, or if he thinks that the oath will be neither pertinent nor probative. ${ }^{80}$

67. See C. Crv. art. 1360 (63e ed. Petits Codes Dalloz 1964).

68. See MAZEAUD, supra note 54, at 414.

69. Even the French admit it is difficult to characterize the judicial nature of the "serment décisoire." See Droit CiviL, supra note 54, Preuve ff 1310.

70. Id.

71. The oath can be delivered only to parties to the lawsuit, and not to third parties. Bodington, supra note 54, at 73.

72. The question must be one pertaining to facts within the personal knowledge of the parties. Id.

73. See C. Crv. art. 1357-65 (63e ed. Petits Codes Dalloz 1964); Bodington, supra note 54, at 72-76; DroIt Civil, supra note 54, Preuve ffi 1311-13; PlaNIOL \& RIPERT, supra note 60, Tा 2293; Stevens, supra note 1, at 380 n.92.

74. C. Crv. art. 1360 (63e ed. Petits Codes Dalloz 1964).

75. Bodington, supra note 54, at 76-77.

76. Id.

77. See J. Vincent, Procédure Ctvile 906 (17e ed. 1974).

78. Stevens, supra note 1 , at 380 n.92.

79. Bodington, supra note 54 , at 75.

80. 2 S. Corniot, DictionnaIre de Droit, Preuve $\uparrow 33$ (2e ed. 1966). 
The other mode of proof that may substitute for a writing is the "aveu," or admission. This is a favored method of proof in the French legal system because it is thought to have a high guarantee of trustworthimess. ${ }^{82}$ When executed before a judge, an admission has the same probative value as a writing. ${ }^{83}$ The admission must be expressed as a declaration, however; silence is not construed as an admission. $^{84}$ Whether a declaration constitutes an admission is decided by the judge. Where a statement is not deemed to constitute an admission, it may still serve as a "beginning of written proof." 85

The decisive oath and the admission are strong modes of proof, but they have not completely eroded the importance of a writing as proof. The oath, because of its drastic nature, is not often used in civil litigation. ${ }^{86}$ One commentator has noted that the admission is not important as a practical matter because if the parties adhere to the agreement, there will be no resort to the courts, and if they do not adhere, it is unlikely that the defendant will admit the good foundation of the plaintiff's claim. ${ }^{87}$

\section{B. The Beginning of Written Proof: The "Foot-in-the-Door" Substitute for a Writing}

Perhaps the most important exception to the writing requirement of article 1341 is found in article 1347 of the Code civil:

The above rules are not applicable when there is a beginning of written proof.

Any instrument emanating from the person against whom the action is brought, or against a person representing him, and rendering probable the fact alleged, is considered a beginning of written proof. 88

81. C. CTv. art. 1356 (63e ed. Petits Codes Dalloz 1964).

- 82. R. Savatier, la ThÉorie des Obligations 253 (3e ed. 1974).

83. Planiol \& RIPERT, supra note 60, $\{\llbracket$ 2281-91. Compare subsection (3)?b) under which an admission made in the pleadings, though not made tefore a judge, will lift the bar of the Statute of Frauds.

84. PLANIOL \& RIPERT, supra note $60, \pi$ 2284. There are no reported cases under subsection (3)(b) on this issue, but silence may be construed as an admission in other areas of American law. See C. MCCORMICK. HandBook OF THE LAW of EvDENCE $\$ 270(b)$ (2d ed. 1972) (testimony as to defendant's silence admissible under admissions exception to the hearsay rule). See also, United States v. Alker, 255 F.2d 851 (3d Cir. 1958).

85. See Drort CiviL, supra note 54, Preuve $\pi 1185$. See text accompanying notes 88-105 infra.

86. See Bodington, supra note 54, at 77; MAZEAUd, supra note 54, at 418.

87. MAzEaud, supra note 54 , at 418 . This argument resembles the criticism leveled against subsection $(3)(b)$ that the subsection will encourage defendants to perjure themselves. See text accompanying notes 15-20 supra.

88. Trannslation from: VoN MEfren, supra note 56, at 869. 
The operation of the beginning of written proof exception indicates that its function is similar to that of Uniform Commercial Code section 2-201, and subsection (3)(b) in particular. In general, the exception requires that there be a writing, that the writing emanate from the party against whom it is offered, and most importantly, that it tend to make the existence of the agreement alleged probable. ${ }^{89}$ The exception has been broadly construed. Any writing may serve as a beginning of written proof, mcluding writings imtended to satisfy the requirements of article 1341 but which are defective in form, ${ }^{00}$ letters, ${ }^{91}$ traders' notebooks, ${ }^{92}$ and admissions and acknowledgments recorded in a previous judgment. ${ }^{93}$

Article 1347 was intended to assist innocent parties who fail to create some proof of an obligation. ${ }^{94}$ Establishing the beginning of written proof is often critical to the plaintiff because once this foundation is established, the imtroduction of proof through witnesses or circumstantial evidence is allowed, as is the use of presumptions. ${ }^{95}$ Since oral testimony may be introduced to establish a beginning of written proof, this exception is commonly regarded as a semi-admission. ${ }^{96}$ If the plaintiff can produce the quantum of oral evidence required by the exception, although this evidence will not be equal in probative value to a full admission, the door will be open for the introduction of other evidence giving the plaintiff an opportunity to prove his case.

One procedure for eliciting oral responses from parties is the "comparution personelle," during this procedure may be accorded weight as a beginning of written proof. The judge orders the personal appearance on his own initiative; he may order it in any case, on any matter. ${ }^{98}$ The parties may be questioned separately or in each other's presence. ${ }^{99}$ They must answer in person, and their answers may not be prepared in advance. In addition, the advocates of the parties may subınit questions which they think might be useful, ${ }^{100}$ and the judge may then pose these questions to the parties.

89. Planiol \& RIPERT, supra note 60 , TI $2272-75$. The exception may also be satisfied by oral testimony. See text accompanying notes 97-105 infra.

90. Drort CiviL, supra uote 54, Preuve $\Uparrow 1051$.

91. Id. \1054, at 82.

92. BoDiNGTON, supra note 54 , at $48-49$.

93. Id.

94. Drort CIVIL, supra note 54, Preuve $\mathbb{1 1} 341$, at 34.

95. MAZEAUD, supra note 54, at 422.

96. DroIt Crvil, supra note 54, Preuve $\Uparrow 1058$.

97. C. Pro. Crv. arts. 324-36 (69e ed. Petits Code Dalloz 1973).

98. See C. Civ. art. 324 (63e ed. Petits Codes Dalloz 1964).

99. NOUvelle RÉPERTOIRE DE DROIT, Comparution personelle et iuterrogatoire ITा 8-12 (Dalloz Supp. 1975).

100. $1 \mathrm{~S}$. CORNIOT, supra note 80 , at Comparution personelle et interrogatoire $\llbracket 4$. 
One advantage of this procedure is that the judge has great discretion in assigning probative value to the responses of the parties. Contradictory, reticent, or ambiguous answers may be deemed to constitute a tacit admission or a beginning of written proof. ${ }^{101}$ If a party does not appear, or appears and does not answer the questions, the judge can construe this as a beginning of written proof. ${ }^{102}$ The judge inay also take into consideration the party's general attitude. ${ }^{103}$ The procedure of the personal appearance, then, effectively permits the judge to aid any person who has no writing to prove the agreement that he has entered. The judge may depart completely from the requirements of article 1341 if responses given or withheld at a personal appearance convimce him that there is adequate proof of the agreement. For example, the judge may find a beginning of written proof in one response; by then taking other responses as circuunstantial evidence, the full proof of an agreement may be found. ${ }^{104}$ This procedure tends to eradicate the entire writing requirement. ${ }^{105}$

Subsection (3)(b), applied broadly, could similarly erode the writing requirement of the Statute of Frauds. ${ }^{106}$ Adopting a flexible approach in assigning probative value to a defendant's responses permits the trier of fact to find that a flustered or ambiguous answer, when considered together with other circumstantial evidence, provides sufficient proof to satisfy the statute. This involves reading the term "admission" in subsection (3)(b) expansively. Such a practice would militate in favor of allowing a plaintiff to proceed to discovery and possibly to trial, since any responses that the plaintiff could elicit from the defendant might prove valuable.

Such a flexible approach inay not be as appropriate under the Uniform Commercial Code, however, as it is in the French system. ${ }^{107}$ The comparative elasticity of the French method of proof may be workable because of features unique to that country's legal system. In France, the judge makes all decisions-there is no jury to be shielded from in-

101. See Drort Crvil, supra note 54, at Preuve $\llbracket$ 1185; ProcÉdure CTVILE, Comparution personelle et iuterrogatoire III 5, 33; VoN MEHREN, supra note 56, at 620-22.

102. C. CIv. art. 336 (63e ed. Petits Codes Dalloz 1964); Von MeHreN, supra note 56 , at 621 .

103. MAZEAUD, supra note 54, at 414 .

104. Id. at 422 .

105. Perillo, supra note 11, at 72 n.186.

106. Subsection (3): b) would have a more limited effect than the personal appearance procedure of the French system, since Article Two of the Uniform Commercial Code applies only to sales of goods while the French personal appearance may be invoked irrespective of the subject matter of the agreement. See note 11 supra.

107. "[W]e ourselves could [not] safely adopt the elastic and somewhat unanalytical methods of proof by which the French system is characterised." Bodington, supra note 54 , at $131-32$. 
formation that it is not competent to handle. ${ }^{108}$ In addition, the principle of the judge's intuitive conviction ("principe d'intime conviction du juge") plays an important role in the French law of evidence. ${ }^{109}$ One aspect of this principle is that where the law does not indicate the probative value to be accorded a certain kind of proof, the judge is free to give the evidence the weight that he thinks it deserves. ${ }^{110}$

Despite these structural differences, there are features of the French system that the United States might find useful to import. Iowa, for instance, has developed rules similar to the French system in the evidentiary role assigned to the Statute of Frauds. The Iowa legislature changed its Statute of Frauds provisions more than a century ago to permit a plaintiff to prove an agreement through the defendant's testimony. ${ }^{111}$ The defendant is precluded from using the Statute of Frauds as a defense unless he can deny the making of the agreement.112 The Iowa statutes thus demonstrate that a rule allowing the court to give "fair consideration" work in an American jurisdiction.

Under the Iowa rule, however, the defendant's denial of the contract will be dispositive of the case. In Deitrick $v$. Sinnott, ${ }^{114}$ the plaintiff alleged that the defendant had agreed to buy some cattle from him. The defendant admitted that in discussing the purchase with the plaintiff he had jokingly said that he would buy the cattle, but he testified that he

108. R. David, French Law: Its Structure, Sources and Methodology 147 n.65 (M. Kindred transl. 1972).

109. Id.

110. See 2 S. Corniot, supra note 80 , Preuve II 14; Planrol \& RIPERT, supra note $60, \uparrow 2194$.

111. 622.34. The above regulations, relating merely to the proof of contracts, shall not prevent the enforcement of those not denied in the pleading, except in cases where the contract is sought to be enforced, or damages recovered for the breach thereof, against some person other than hin who made it.

622.35. The oral evidence of the maker against whom the unwritten contract is sought to be enforced shall be competent to establish the same.

IOWA CODE ANN. $\$ \S 622.34-35$ (1950). With the repeal of the Uniform Sales Act and the adoption of the Uniform Commercial Code iu Iowa, these sections no longer apply in sale-of-goods cases. They continue, however, to apply in other cases. See Hudson, Contracts in lowa Revisited-1966, 15 DRAKE L. REv. 61, 76-77 (1966).

112. See, e.g., Olsen v. Peregoy \& Moore Co., 182 Iowa 889, 165 N.W. 202 (1917). The plaintiff sought a landlord's lien due to the defendant's repudiation of a 5-year lease. Checks were admitted into evidence, which the defendant's agent testified he had sent to the plaintiff in payment of 1 year's rent. The defendant testified that he had been advised by his attorney that the lease was enforceable for 1 year only. The court held that this testimony, together with the checks sent by the agent for the payment of rent, was an admission that the oral agreement was made, taking the contract out of the Statute of Frauds. Since the defendant was found to have admitted the existence of the agreement, the question of whether the defendant was bound for more than 1 year was one of law, to be decided by the court.

113. Id. at $890,165 \mathrm{~N} . \mathrm{W}$. at 202 .

114. 189 Iowa 1002, 179 N.W. 424 (1920). 
had had no intention of doing so and that the plaintiff had known this. The court refused to admit the testimony offered by the plaintiff that the proposition had been serious saying:

The testimony of the defendant, under all the holdings of this court, upon the question of the oral contract, was conclusive, and the court cannot say that he is not telling the truth about the matter. ${ }^{115}$

Given these circumstances, a French court might reach a different result. Utilizing the personal appearance procedure, a French court might characterize the defendant's declarations as an adinission, or at least as a beginning of written proof. ${ }^{110}$ The approach of the Iowa court in Deitrick is similar, in operative effect, to the French procedure of the decisive oath. In France, if the serment décisoire is invoked, it precludes every other source of proof. The decision cannot be reversed, even in an action for perjury. Although the defendant may be penalized for perjury, the civil judgment will remain. ${ }^{117}$

The prevailing view of the effect of a denial under both subsection (3)(b) and the Iowa rules-that a denial is dispositive of the plaintiff's case - can be supported on similar grounds. ${ }^{118}$ The plaintiff, by failing to procure a writing, has voluntarily adopted subsection (3)(b) as the method of proving the contract. He therefore must be prepared to run the risk of the defendant's false denial, even when the defendant's falsehood is contradicted by other evidence. The plaintiff should be permitted to proceed to discovery. If the defendant denies the contract at the discovery stage, however, his denial should be honored. Policy reasons support this result. Subsection (3)(b) requires that two coinpeting interests be balanced: allowing the plaintiff his day in court and protecting the defendant froin unwarranted lawsuits. To strike a balance, there must be some point at which the defendant's denial is honored and the plaimtiff is allowed to proceed no further. This involves the risk of concluding a meritorious plaintiff, and allowing a perjuring defendant to successfully evade an oral contract. Yet, if preventing harassment of a potentially innocent defendant is to remain a purpose of the Statute of Frauds, such a risk must be assumed.

\section{CONCLUSION}

Uniform Commercial Code section 2-201 presents a cohesive approach to the issue of what evidence of a contract is sufficient to protect

115. Id. at 1010, 179 N.W. at 428.

116. See text accompanying notes 101-05 supra.

117. See text accompanying notes 69-80 supra.

118. But see Reisman Int'1 Corp. v. J.S.O. Wood Prods., Inc., 10 UCC REP. SERv. 1165 (Civ. Ct. N.Y. County 1972) (plaintiff allowed to proceed to discovery despite defendant's denial of the contract in his answer). See text accompanying notes $36-38$ supra. 
against fraudulent claims. Subsection (3)(b) provides a mechanism for the enforcement of oral agreements, thus enabling people to rely on the oral agreements that are constantly made in the ordimary course of business. By allowing an admission to substitute for the traditional requirement of a writing, the subsection attempts to bring the law into accord with business practice. If subsection (3)(b) is to be more than mere formalism, however, its implementation must reflect the balancing of competing interests. The plaintiff should be allowed to examine the defendant, either through discovery procedures or at trial. To minimize the harassment of innocent defendants, the defendant's denial at any stage of the proceedings after the pleadings should be given full effect, unless it is contradicted by a previous admission. ${ }^{119}$ If the defendant denies the making of the agreement in discovery, the suit should be discontinued. Although according such weight to a denial increases the likelihood that the defendant may perjure himself, subsection (3)(b) seems to be based on the premise that there is something to be gained in requiring the defendant specifically to deny the existence of the agreement. ${ }^{120}$ If the defendant gives an equivocal answer, the court should be able to give a "fair consideration" to the defendant's testimony. This fulfills the policies behind subsection (3) (b) while transforming it into a more powerful device. Applied in this manner, subsection (3)(b) will become a sensible and practical procedure for providing proof of an agreement in the absence of a writing.

Frances Jan Malinowski*

119. See text accompanying notes $40-45$ supra.

120. See Stevens, supra note 1. Law.

* B.A. 1970, University of Michigan; third-year student, Boalt Hall School of 